\title{
Chondrichthyans of the San Matías Gulf, Patagonia, Argentina
}

\author{
María R. PERIER ${ }^{1,2}$, Marilú ESTALLES ${ }^{1,3}$, Nidia M. COLLER ${ }^{1,2}$, Matías N. SUAREZ $^{1,2}$, \\ Gimena J. MORA ${ }^{1} \&$ Edgardo E. DI GIÁCOMO ${ }^{1,2}$
}

\begin{abstract}
${ }^{1}$ Grupo CONDROS. Instituto de Biología Marina y Pesquera "Alte. Storni”, Güemes 1030, 8520 San Antonio Oeste, Río Negro, Argentina. raquelperier@gmail.com. ${ }^{2}$ Universidad Nacional del Comahue (UNCo). edgardodigiacomo@gmail.com. ${ }^{3}$ Consejo Nacional de Investigaciones Científicas y Técnicas (CONICET). ml.estalles@conicet.gov.ar/mariluestalles@gmail.com
\end{abstract}

\begin{abstract}
The San Matías Gulf (SMG; $41^{\circ}-42^{\circ} \mathrm{S} ; 64^{\circ}-65^{\circ} \mathrm{W}$ ) is the largest gulf in Northern Patagonia, Argentina. $\mathrm{Up}$ to date, the chondrichthyan fauna of this area has not been reported. Therefore, the aim of this work is to provide a list with species presence and biological characteristics of the chondrichthyans recorded in SMG during the last 30 years. A total of 13 sharks distributed in 11 families, 19 skates and rays distributed in six families, and one holocephalan have been so far recorded in SMG. From the zoogeographical point of view, this chondrichthyan fauna is a mixed assemblage of species typically found in the Argentinean and Magellanean Provinces. The holocephalan Callorhinchus callorynchus is the most landed chondricthyan of the local fishery. With it, five sharks and seven skates are also exploited.
\end{abstract}

Key words: Holocephali, Elasmobrachii, Batoidea, Southwest Atlantic, Patagonia.

Resumen: Los condrictios del Golfo San Matías, Patagonia, Argentina. El Golfo San Matías (SMG; $41^{\circ}$ $42^{\circ} \mathrm{S}-64^{\circ}-65^{\circ} \mathrm{O}$ ) se encuentra ubicado en el norte de la Patagonia, Argentina. Hasta la fecha no se cuentan con reportes de la fauna de condrictios de esta zona. Por lo tanto, el objetivo de este trabajo es proporcionar una lista de la presencia y las características biológicas de los condrictios registrados en el SMG durante los últimos 30 años. Un total de 13 tiburones distribuidos en 11 familias, 19 batoideos distribuidos en seis familias y un holocefalo han sido reportados para la zona. Desde el punto de vista zoogeográfico, el SMG presenta un ensamble de especies pertenecientes a las Provincias Magallánica y Argentina. El holocefalo Callorhinchus callorynchus es el condrictio más desembarcado de la pesquería local. Con menor importancia son explotadas comercialmente, cinco especies de tiburones y siete de rayas.

Palabras clave: Holocephali, Elasmobrachii, Batoidea, Atlántico suroccidental, Patagonia.

\section{INTRODUCTION}

The San Matías Gulf (SMG; $41^{\circ}-42^{\circ} \mathrm{S} ; 64^{\circ}-$ $65^{\circ} \mathrm{W}$ ) is the largest gulf of Northern Patagonia, Argentina (Fig. 1). This gulf is a semi-closed basin separated from the adjacent continental shelf by an $80 \mathrm{~m}$-deep sill. Hydrographically, a thermohaline front with NE-SW direction divides the gulf during spring-summer into two water mass (Perier \& Di Giácomo, 2002). The northern water mass presents from 1 to $3^{\circ} \mathrm{C}$ temperature and $2 \%$ salinity more than the southern one (Di Giácomo et al., 1993; Piola \& Scasso, 1988). The dynamics of this front is associated with the presence and spawning areas of several fishes such us the common hake Merluccius hubbsi, the savorín Seriolella porosa and the holocephalan Callorhinchus callorynchus (Di Giácomo, 1992; Di Giácomo \& Perier, 1992; Perier \& Di Giácomo, 2002).

A bottom trawl fishery, an economically important activity in the region, has been established in SMG since 1971. Its annual landings are around 13,000 t. The common hake is the target species and chondrichthyans are captured as bycatch (Di Giácomo \& Perier, 1991; 1992). C. callorynchus is the most landed chondrichthyan (Di Giácomo \& Perier, 1992). With an average of $1060 \mathrm{t}$ landed between 2009 and 2010. Batoids (skates and rays) are in second place with $350 \mathrm{t}$, followed by sharks with 160 tons.

The study of chondrichthyans of SMG for- 


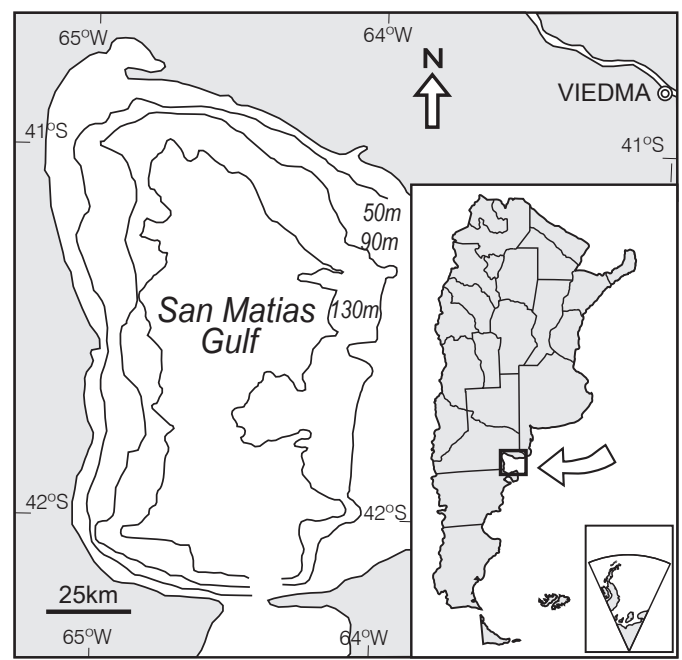

Fig. 1: Spatial location of the San Matías Gulf.

mally started in 1984 when the biological characteristics and commercial exploitation of C. callorynchus (Di Giácomo, 1990) have been initially described. Since then, studies on distribution, biology and commercial exploitation have been carried out on several fish species (Di Giácomo, 1992; Di Giácomo \& Perier, 1991; 1994; 1996; Di Giácomo et al., 1994; 2009; Van der Molen et al., 1998; Awruch et al., 2008; Perier et al., 2010; Coller et al., 2011; Estalles et al., 2011). However, basic information such as species composition has remained unpublished. Therefore, the aim of this work is to report the presence and some biological characteristics of the chondrichthyan fauna of SMG.

\section{MATERIALS AND METHODS}

The present work is based on the reported records of chondrichthyan species during the last 30 years in SMG. Sharks and holocephalans were classified according to Compagno (2005). The systematic hierarchy of the list comprises : Class, Subclass, Infraclass, Cohorte, Superorder, Order, Family, Scientific name, Authorship, English and Spanish common names. Species were listed alphabetically within the families.

Fish species distribution and English and Spanish common names were extracted from Fishbase (Froese \& Pauly, 2011), Cousseau et al. (2007), Compagno (2005), Menni \& Stehmann (2000), Chiaramonte (1998), McEachran (1983) and Figueiredo (1977). Maximum total length recorded for fish species considering male and female, commercially exploited and rare species were also indicated. Species were considered rare when their occurrence were registered less than five times in SMG in the surveyed period.

Species recordings and their maximum total lengths were obtained from three different sources. Bottom trawl surveys from 1986; 1993 to 1997 ; 2004 to 2007 , samplings at local fishprocessing plants from 2007 to 2009 and commercial catches by onboard observers from 2007 to 2009. Bottom trawl surveys were performed to assess the stocks of the demersal species of SMG (Fig. 1) and were conducted during spring. For each bottom trawl survey several number of hauls (30-40) of 30 minutes each were performed covering a depth-range of $40-175 \mathrm{~m}$, according to the methods described by Di Giácomo \& Perier (1991; 1992). During 2007 the bottom trawl survey design was changed and a systematic sampling was adopted.

\section{RESULTS}

A total of 13 sharks distributed in 11 families, 19 skates and rays distributed in six families, and one holocephalan have been recorded in SMG. These species represent 33 and $44 \%$ of the sharks and batoids, respectively, and one of the two chimaeras reported for the Argentine Sea (Menni \& Lucifora, 2007).

According to the classification followed by Balech \& Ehrlich (2008), SMG is situated in the limit between the Bonaerensean District of the Argentinean Province and the Patagonian District of the Magellanean Province. As a result, the chondrichthyan fauna of SMG is a mixed assemblage of species typically found in these two provinces. Only for the skates Atlantoraja platana and Psammobatis lentiginosa SMG is considered their main distributional area in the Argentine sea.

\section{ANNOTATED TAXONOMIC LIST OF THE REPORTED RECORDS}

Class Chondrichthyes

Subclass Holocephali

Order Chimaeriformes

Family Callorhinchidae

Callorhinchus callorynchus (Linnaeus, 1758). Elephant fish, Cockfish- Pez gallo, Pez elefante. This species is distributed in the Southeast Pacific and Southwest Atlantic, from Chile to Argentina.and through the Beagle channel. 
Remarks. The main concentrations of $C$. $c a$ llorynchus within SMG are found in its northern area between 20 and $50 \mathrm{~m}$ depth. The reproductive activity of the species extends throughout the year. Length at maturity was estimated at 40 and $49 \mathrm{~cm}$ standard length (SL) for males and females respectively. Maximum length recorded for males was $85 \mathrm{~cm}$ SL and $102 \mathrm{~cm}$ SL for females. This species is the most landed chondrichthyan species of the bottom trawl fishery of $S M G$. During the 1971- 1989 period it was the second most landed fish of the local fishery.

References. Di Giácomo \& Perier (1991; 1994); Di Giácomo (1992); López et al. (2000) and Menni et al. (2007).

\section{Subclass Elasmobranchii Infraclass Euselachii Cohorte Neoselachii Subcohorte Selachii \\ Superorder Squalomorphi Order Hexanchiformes Family Hexanchidae}

Notorynchus cepedianus (Péron, 1807). Broadnose sevengill shark- Gatopardo, Tiburón moteado. This species is distributed worldwide in temperate seas. In the Southwest Atlantic it is found from southern Brazil to the beagle channel $\left(55^{\circ} \mathrm{S}\right)$.

Remarks. This species is commercially exploited in $S M G$. Maximum length recorded for males was $204 \mathrm{~cm}$ TL and $186 \mathrm{~cm}$ TL for females.

\section{Order Squaliformes \\ Family Squalidae}

Squalus acanthias Linnaeus, 1758. Piked dogfish- Espinillo. This species has a worldwide range distributon. In the Western Atlantic it is found from Greenland to Argentina.

Remarks. The main concentrations of $S$. acanthias within $S M G$ were found in its southeast area between 86 and $105 \mathrm{~m}$ depth. Maximum total lengths were 94 and $101 \mathrm{~cm}$ TL for males and females respectively. This species is not commercially exploited by the local fishery, individuals caught are discarded on board.

Reference. Di Giácomo et al. (2009).

$$
\begin{aligned}
& \text { Order Squatiniformes } \\
& \text { Family Squatinidae }
\end{aligned}
$$

Squatina guggenheim Marini, 1936. Angular angel shark- Pez ángel. This species is endemic to the Southwest Atlantic. It is distributed from southern Brazil to Argentina as far south as central Patagonia.

Remarks. Maximum lengths recorded were 88 and $96 \mathrm{~cm}$ TL for males and females respectively in SMG. Both sexes matured at similar sizes between 73 and $76 \mathrm{~cm}$ TL. This species shows a biannual or triannual reproductive cycle according with the authors with gestation taking one year. This species is commercially exploited by the local fishery. Reference. Colonello et al. (2007) and Awruch et al. (2008).

\section{Superorder Galeomorphii \\ Order Lamniformes \\ Family Odontaspididae}

Carcharias taurus Rafinesque, 1810. Sand tiger shark- Escalandrún. This species is found in all warm seas except the eastern Pacific. In the Western Atlantic, it is distributed from Canada to Argentina.

Remarks. Its presence in SMG is rare.

$$
\text { Family Alopiidae }
$$

Alopias vulpinus (Bonnaterre, 1788). Thresher shark- Tiburón zorro. This species is found worldwide in temperate and tropical seas. In the Western Atlantic, it is distributed from Canada to Argentina.

Remarks. The presence of this species is rare. Their ocurrence in SMG was reported by local fishermen.

\section{Family Cetorhinidae}

Cetorhinus maximus (Gunnerus, 1765). Basking shark- Tiburón peregrino. This species is worldwide distributed. In the Western Atlantic, it is found from Canada to Argentina.

Remarks. The presence of this species is rare. Only two individuals have been recorded in SMG. The maximum length recorded was $540 \mathrm{~cm}$ TL for a female.

Reference. Di Giácomo (1991).

Family Lamnidae

Isurus oxyrinchus Rafinesque, 1810. Shortfin mako- Mako. This species is found worldwide in temperate and tropical seas. In Western Atlantic, it is found from Canada to northern Patagonia, Argentina.

Remarks. The presence of this species is rare. 
Only one female of $150 \mathrm{~cm}$ TL has been recorded in SMG.

\section{Order Carcharhiniformes \\ Family Scyliorhinidae}

Schroederichthys bivius (Müller \& Henle, 1838). Narrowmouthed catshark- Pintarroja. It is distributed in the Southeast Pacific and Southwest Atlantic, from central Chile to southern Brazil.

Remarks. Maximum length recorded was $86 \mathrm{~cm}$ TL for an individual of unknown sex in $S M G$. This species is occasionally found among commercial species of the local fishery.

Reference. Soto, 2001.

\section{Family Triakidae}

Galeorhinus galeus (Linnaeus, 1758). Tope shark- Cazón. This species is widely distributed in temperate seas. In the Southwest Atlantic it is found from southern Brazil to northern Patagonia, Argentina.

Remarks. Maximum lengths recorded were 156 and $146 \mathrm{~cm}$ TL for males and females respectively in $S M G$. This species is commercially exploited by the local fishery.

Mustelus schmitti Springer, 1939. Narrownose smooth-hound- Gatuzo. This species is endemic to the Southwest Atlantic. It is distributed from southern Brazil to south Patagonia, Argentina.

Remarks. Maximum lengths recorded were 95 and $100 \mathrm{~cm}$ TL for males and females respectively in SMG. This species is commercially exploited by the local fishery.

References. Chiaramonte \& Pettovello (2000)

Family Carcharhinidae

Carcharhinus brachyurus (Günther, 1870). Copper shark- Bacota. This species is mainly found in temperate waters. In the Southwest Atlantic it is distributed from Rio de Janeiro to northern Patagonia, Argentina.

Remarks. Maximum length recorded was $264 \mathrm{~cm}$ for a male in SMG. This species is commercially exploited by the local fishery.

Prionace glauca (Linnaeus, 1758). Blue sharkTiburón azul. This species is distributed worldwide in temperate and tropical waters. In the Western Atlantic, it is found from Canada to Argentina.

Remarks. The presence of this species in SMG is rare.
Family Sphyrnidae

Sphyrna zygaena (Linnaeus, 1758). Smooth hammerhead- Tiburón martillo. This species is distributed in temperate and tropical seas. In the Western Atlantic, it is found from Canada to northern Patagonia, Argentina.

Remarks. Only one individual has been recorded in SMG. The presence of this species is rare.

\section{Superorder Batoidea \\ Order Torpediniformes \\ Family Torpedinidae}

Torpedo puelcha Lahille, 1926. Argentine torpedo- Torpedo. This species is endemic to the Southwest Atlantic. It is distributed from southern Brazil to northern Patagonia, Argentina.

Remarks. The presence of this species is rare. Only one female of $70 \mathrm{~cm}$ TL has been recorded in SMG.

\section{Family Narcinidae}

Discopyge tschudii Heckel, 1846. Apron ray, Electric ray- Raya eléctrica. It is distributed in the Southeast Pacific and Southwest Atlantic, from Peru to southern Argentina.

Remarks. Maximum length recorded were 43 and $38 \mathrm{~cm}$ TL for males and females respectively in SMG. This species is not commercially exploited by the local fishery, individuals caught are discarded on board.

Reference. Estalles et al. (in press).

Order Rajiformes

Family Arhynchobatidae

Atlantoraja castelnaui (Miranda Ribeiro, 1907). Spotback skate- Raya a lunares. This species is endemic to the Southwest Atlantic. It is distributed form southern Brazil to northern Patagonia, Argentina.

Remarks. Maximum lengths recorded were 112 and $147 \mathrm{~cm}$ TL for males and females respectively in SMG. This species is commercially exploited by the local fishery.

Reference. Estalles et al. (2011).

Atlantoraja cyclophora (Regan, 1903). Eyespot skate- Raya ojona, Raya de círculos. This species is endemic to the Southwest Atlantic. It is distributed form southern Brazil to northern Patagonia, Argentina. 
Remarks. Maximum lengths recorded were 62 and $69 \mathrm{~cm}$ TL for males and females respectively in SMG. Size at maturity was estimated at 53 and $59 \mathrm{~cm}$ TL for males and females. This species is commercially exploited by the local fishery.

Reference. Estalles et al. (2011).

Atlantoraja platana (Günther, 1880). La Plata skate- Raya platana, Raya oscura. This species is endemic to the Southwest Atlantic. It is found in southern Brazil and SMG.

Remarks. San Matías Gulf is the main distribution area of A. platana in the Argentine Sea. Maximum lengths recorded were 81 and 91 cm TL for males and females respectively. This species is commercially exploited by the local fishery.

References. Coller et al. (2011) and Estalles et al. (2011).

Bathyraja brachyurops (Fowler, 1910). Broadnose skate- Raya de cola corta. This species is distributed in the Southeast Pacific and Southwest Atlantic, from Chile to southern Brazil.

Remarks. The presence of this species is rare. This species has been recorded twice in SMG. Maximum lengths recorded were 72 and $77 \mathrm{~cm}$ TL for males and females respectively.

Reference. Estalles et al. (2011).

Bathyraja multispinis (Norman, 1937). Multispine skate- Raya aserrada. This species is distributed in the Southeast Pacific and Southwest Atlantic, from Chile to Uruguay.

Remarks. The presence of this species in SMG is rare. Maximum length recorded was $81 \mathrm{~cm}$ TL for one specimen of unknown sex.

Bathyraja macloviana (Norman, 1937). Patagonian skate- Raya espinosa. This species is distributed in the Southeast Pacific and Southwest Atlantic, from Chile to Uruguay.

Remarks. The presence of this species is rare. Only one female of $60 \mathrm{~cm}$ TL has been recorded in SMG.

Psammobatis lentiginosa McEachran, 1983. Freckled sand skate- Raya lentiginosa. This species is endemic to the Southwest Atlantic. It is found from southern Brazil to northern Patagonia as far as San Jorge Gulf (Cousseau et al., 2007).

Remarks. So far, the main distribution area of P. lentiginosa is $S M G$ in the Southwest Atlantic.
It presents a continuous reproductive cycle with the peak of egg-case production during autumn. Maximum lengths recorded were 55 and $52 \mathrm{~cm}$ TL for males and females. Both sexes matured at similar sizes, $41 \mathrm{~cm}$ TL. Due to its small size, individuals caught by the local fishery are discarded onboard.

Reference. Perier et al. (2010).

Psammobatis bergi Marini, 1932. Blotched sand skate- Raya marmolada. This species is endemic to the Southwest Atlantic. It is found from Uruguay to northern Patagonia, Argentina.

Remarks. Maximum lengths recorded were 51 and $46 \mathrm{~cm}$ TL for males and females respectively in SMG. This species is found sporadically among commercial species of the local fishery.

Psammobatis rudis Günther, 1870. Smallthorn sand skate- Raya de hocico corto. This species is distributed in the Southeast Pacific and Southwest Atlantic, from Chile to Uruguay.

Remarks. The presence of this species is rare. Only one female of $21 \mathrm{~cm}$ TL has been recorded in SMG.

Rioraja agassizii (Müller \& Henle, 1841). Rio skate- Raya lisa. This species is endemic to the Southwest Atlantic. It is distributed from southern Brazil to northern Patagonia, Argentina.

Remarks. The presence of thos species is rare. Maximum lengths recorded were 52 and $59 \mathrm{~cm}$ TL for males and females respectively in $S M G$. This species is commercially exploited by the local fishery.

Reference. Estalles et al. (2011).

Sympterygia bonapartii Müller \& Henle, 1841. Smallnose fanskate- Raya marmorada. This species is distributed in the Southeast Pacific and Southwest Atlantic, from southern Chile to southern Brazil.

Remarks. Maximum lengths recorded were 69 and $75 \mathrm{~cm}$ TL for males and females respectively in SMG. Size at maturity was estimated at 56 and $59 \mathrm{~cm}$ TL for males and females. This species is commercially exploited by the local fishery.

Reference. Estalles et al. (2011).

Sympterygia acuta Garman, 1877. Bignose fanskate- Raya picuda. This species is endemic to the Southwest Atlantic. It is found from southern Brazil to northern Patagonia, Argentina. 
Remarks. Only a few individuals, most of them immature have been recorded in SMG. Maximum lengths recorded were 25 and $50 \mathrm{~cm}$ TL for males and females respectively.

\section{Family Rajidae}

Amblyraja doellojuradoi (Pozzi, 1935). Southern thorny skate- Raya erizo. This species is distributed in the Southeast Pacific and Southwest Atlantic, from Chile to Uruguay. Remarks. The presence of this species in SMG is rare.

Dipturus trachyderma (Krefft \& Stehmann, 1975). Ray- Raya de vientre áspero. This species is distributed in the Southeast Pacific and Southwest Atlantic, from Chile to southern Brazil.

Remarks. Maximum lengths recorded were 90 and $125 \mathrm{~cm}$ TL for males and females respectively in $S M G$. This species is commercially exploited by the local fishery.

Reference. Estalles et al. (2011).

Zearajachilensis (Guichenot,1848). Yellownose skate- Raya hocicuda. This species is distributed in the Southeast Pacific and Southwest Atlantic, from Chile to southern Brazil.

Remarks. Maximum lengths recorded were 100 and $119 \mathrm{~cm}$ TL for males and females respectively in SMG. Size at maturity was estimated at 83 and $93.5 \mathrm{~cm}$ TL for males and females. This species is commercially exploited by the local fishery.

Reference. Estalles et al. (2011).

\section{Order Myliobatiformes Family Dasyatidae}

Dasyatis hypostigma Santos \& de Carvalho, 2004. Eagle ray- Raya látigo. This species is endemic to the Southwest Atlantic. It is distributed from southern Brazil to SMG.

Remarks. The presence of this species is rare. Only one female of $95 \mathrm{~cm}$ TL has been recorded in SMG.

\section{Family Myliobatidae}

Myliobatis goodei Garman, 1885. Southern eagle ray- Chucho. This species is distributed in the Atlantic from the United States to northern Patagonia, Argentina.

Remarks. This species is frequently captured by recreational fishermen in SMG. Maximum length recorded was $97 \mathrm{~cm}$ TL for females.

\section{ACKNOWLEDGMENTS}

We thank the local fish-processing plants for providing us with the biological material and allowing us to sample at their facilities, and local fishermen for their reports. We also thank technicians for their help with the samplings. This research was supported by Universidad Nacional del Comahue grant: "Pez gallo, rayas y tiburones del Golfo San Matías: Hacia una explotación pesquera sustentable 004/M020". This was a contribution of the Group of Study of Chondrichthyan Fishes "CONDROS".

\section{BIBLIOGRAPHY}

Awruch, C., F.L. Lo Nostro, G.M. Somoza \& E.E. Di Giacomo. 2008. Aspects of the reproductive biology of angel shark, Squatina guggenheim (Chondrichthyes: Squatinidae) off Patagonia (Argentina, southwestern Atlantic). Cs. Mar. 34 (1): 17- 28.

Balech, E. \& M.D. Ehrlich. 2008. Esquema biogeográfico del Mar Argentino. Revista de Investigación y Desarrollo Pesquero, 19: 45-75.

Chiaramonte, G.E. 1998. The shark genus Carcharhinus Blainville, 1816 (Chondrichthyes: Carcharhinidae) in Argentine waters. Mar Freshw Res., 49: 747752

Chiaramonte, G. E. \& A.D. Pettovello. 2000. The biology of Mustelus schmitti in Southern Patagonia, Argentina. Journal of Fish Biology. 57: 930-992.

Colonello, J.H., L.O. Lucifora \& A.M. Massa. 2007. Reproduction of the angular shark (Squatina Guggenheim): geographic differences, reproductive cycle and sexual dimorphism. ICES J. Mar. Sci., 64: 131-140.

Coller, N.M., M.R. Perier \& E.E. Di Giácomo. 2011. Dimorfismo sexual y relaciones morfométricas de Atlantoraja platana (Günther, 1880) en aguas del golfo San Matías, Patagonia. Rev. Mus. Arg. Cs. Nat. n.s, 13(1): 1-5.

Compagno, L.J.V. 2005. Checklist of living chondrichthyes. En: W.C. Hamlett (Ed), Reproductive Biology and Phylogeny of Chondrichthyes. Sharks, Batoids and Chimaeras. Science Publishers, Inc., Enfield, New Hampshire, USA, pp. 503-548.

Cousseau, M.B., D.E. Figueroa, J.M. Díaz de Astarloa, E. Mabragaña \& L.O. Lucífora. 2007. Rayas, chuchos y otros batoideos del Atlantico Sudoccidental $\left(33^{\circ}-55^{\circ} \mathrm{S}\right)$. Special Publications. INIDEP, Mar del Plata, Argentina. 102 pp.

Di Giácomo, E.E. 1990 Contribución al estudio biológico- pesquero del Pez gallo, Callorhynchus callorhynchus (Linne, 1758) Berg, 1895, en el Golfo San Matías. Trabajo de Tesis para optar al grado de Doctor en Ciencias Naturales (Orientación Zoología). Facultad de Ciencias Naturales y Museo. Universidad Nacional de la Plata. 174 pp.

Di Giácomo, E.E. 1991. Tiburón peregrino, un raro hal- 
lazgo. Subaquática, III (9): 26.

Di Giácomo, E.E. 1992. Distribución de la población de pez gallo (Callorhinchus callorhynchus) en el Golfo San Matías, Argentina. Frente Marítimo, 12 (A): 113-118.

Di Giácomo, E.E. \& M.R. Perier. 1991 Evaluación de la biomasa y explotación comercial del pez gallo (Callorhynchus callorhynchus) en el Golfo San Matías, Argentina. Frente Marítimo, 9 (A): 7-13.

Di Giácomo, E.E. \& M.R. Perier. 1992. Abundancia, estructura poblacional y zona de desove de la merluza (Merluccius hubbsi) en el Golfo San Matías, Argentina. Frente Marítimo, 12 (A): 47-52.

Di Giácomo, E.E. \& M.R. Perier. 1994. Reproductive biology of the cockfish, Callorhynchus callorhynchus (Holocephali: Callorhynchidae), in Patagonian waters (Argentina). Fish Bull, 92: 531-539.

Di Giácomo, E.E. \& M.R. Perier. 1996. Feeding habits and prey selection by cockfish, Callorhinchus callorhynchus in patagonian waters, Argentina. Mar Freshw Res., 47: 801-808.

Di Giácomo, E.E., J. Calvo, M.R. Perier \& E.R. Morriconi. 1993. Spawning aggregations of Merluccius hubbsi, in patagonian waters: evidence for a single stock? Fish Res., 16: 9-16.

Di Giácomo, E.E., A.M. Parma \& J.M. Orensanz. 1994. Food consumption by the cock fish, Callorhynchus callorhynchus (Holocephali: Callorhynchidae), from Patagonia (Argentina). Environ. Biol. Fishes, 40:199-211.

Di Giácomo, E.E., M.R. Perier \& N.M. Coller. 2009. Reproduction of spiny dogfish Squalus acanthias in San Matías Gulf, Patagonia (Argentina). En: V.F. Gallucci, G.A. Mc Farlane \& G.G. Bargmann (Eds), Biology and Management of Dogfish Sharks. American Fisheries Society, USA. pp 209- 215.

Estalles, M., N.M. Coller, M.R. Perier \& E.E. Di Giácomo. 2011. Skates in the demersal trawl fishery of San Matías Gulf: species composition, relative abundance and maturity stages. Aquat. Living Resour., 1-7. doi: 10.1051/alr/2011119

Estalles, M., N.M. Coller, E.E. Di Giácomo \& M.R. Perier. (in press). Distribution and reproductive biology of the electric ray Discopyge tschudii Heckel, 1846 in San Matías gulf, Northern Patagonia, Argentina.
Neotropical Ichthyology.

Figueiredo, J.L. 1977. Manual de Peixes Marinhos do Sudeste do Brasil. I. Introdução. Cações, raias e quimeras. Museu de Zoologia- Universidade do Sâo Paulo, Sâo Paulo, Brazil. 104 pp.

Froese, R. \& D. Pauly. 2011. FishBase, World Wide Web electronic publication, Available from: http://www. fishbase.org./ (version 02/2011). (Last accessed 6 June 2011).

López, H.L., N.A. San Román \& E.E. Di Giácomo. 2000. On the South Atlantic distribution of Callorhinchus callorhyn chus (Holocephali: Callorhynchidae). J of Appl. Icht. 16 (1): 39.

McEachran, J.D. 1983. Results of the research cruises of FRV "Walther Herwig" to South America. LXI. Revision of the South American skate genus Psammobatis Günther, 1870 (Elasmobranchii: Rajiformes, Rajidae). Archive für Fischereiwissesnschaft, 34 (1): 23-80.

Menni, R.C., R.A. Ferriz \& L.O. Lucífora. 2007. Condrictios de la Argentina y Uruguay. Lista de Trabajo. ProBiota, FCNyM, UNLP, Serie TécnicaDidáctica, La Plata, Argentina. 11: 1-15.

Menni, R.C. \& F.W. Stehmann. 2000. Distribution, environment and biology of batoid fishes off Argentina, Uruguay and Brazil. A review. Rev. Mus. Arg. Cs. Nat. n.s., 2 (1): 69-109.

Perier, M.R. \& E.E. Di Giácomo. 2002. El Savorín Seriolella porosa como un recurso estacional en el Golfo San Matías, República Argentina. Rev. Inves. Desar. Pesq., 15: 15- 26.

Perier, R., M. Estalles, N.M. Coller \& E.E. Di Giácomo. 2010. Reproductive biology of the endemic skate Psammobatis lentiginosa in the San Matías Gulf (South-Western Atlantic). J. Mar. Biol. Ass. UK., 1-9. doi:10.1017/S0025315410001347.

Piola, A.R. \& L.M. Scasso. 1988. Circulación en el Golfo San Matías. Geoacta, 15(1): 33-51.

Soto, J.M.R. 2001. Annotated systematic checklist and bibliography of the coastal and ocean fauna of Brazil. I. Sharks. Mare Magnum 1 (1):51-120.

Van der Molen, S., G. Caille \& R. González. 1998. Bycatch of sharks in patagonia coastal trawl fisheries. Mar Freshw Res., 49: 641-644. 
